\title{
벨기에 대외원조 현황
}

유럽 국가의 개발원조는 원조가 시작된 그 동기에서 우리나라와 많이 다른 것이 분명하나 원조 제공 의 방법이나 이념, 전략 등에서는 신생 원조 공여국인 우리에게 시사하는 바가 크다 하겠다. 벨기에의 경우 직접적인 양자지원을 실시하는 나라는 18 개국에 불과하며, 원조의 대부분을 중앙아프리카 지역 에 집중하고 있다. 또한 개도국으로의 개발협력에 $80 \%$ 이상의 국민이 지지를 보내고 있다. 유럽국가 들의 원조 행태 연구가 우리나라 공적개발원조의 방향성을 확립하는데 많은 보탬이 될 것이다. 한편, 벨기에를 포함한 많은 유럽 국가들은 각 국가 개별적으로도 원조를 실시하면서 동시에 그들의 지역연 합체인 $\mathrm{EU}$ 를 통해서도 개발협력을 실시하고 있다. [정리 : 정책연구실]

\section{ODA 전략}

\section{ODA 전략}

- $\mathrm{DAC}$ 및 $\mathrm{EU}$ 의 회원국으로써, $\mathrm{DAC}$ 및 $\mathrm{EU}$ 의 개발 정책에 부합

- 개발원조 정책의 유럽화: EU의 개발원조정책 에 관한 the European Consensus on Development 이행

- EU의 주 정책 중 하나인 굿거버넌스를 개 발정책에 포함시키기 위해 노력 중
- MDGs 달성에 동참하며 Fragile State 우선 고려

- 2005년 원조의 효과성 제고를 위한 파리선언 이행

- 파리선언 이행의 걸림돌이 된 법조항 중 $\mathrm{BTC}$ 가 프로젝트를 직접 집행해야 된다는 조항을 삭제, 현재는 수원국이 직접 프로젝 트 집행 가능

- 몬테레이 협약에 의거 2010년까지 GNI대비 $0.7 \%$ 목표 설정 
※ 벨기에는 유럽연합이 2010년 GNI대비 $0.51 \%$ 목표에 비해 앞서가고 있음. 다만 최근 벨기에 의 $\mathrm{ODA}$ 증가는 부채탕감에 의한 것임을 감안 (2003년 ODA의 40\%, 2005년도 ODA의 $37 \%)$ 하면 새로운 재원이 필요

\section{ODA 집중화 및 확대}

- $\mathrm{ODA}$ 의 집중화

- 1999년 국제협력법

- 직접 양자 지원을 최대 25 개 국가로 한정

- 5 개의 집중 지원 분야를 명시하며 지속가 능한 개발을 목표로 함

- 지원 다자기구를 20 개로 한정

- 아동권리에 관한 조항 국제협력법에 포함

- 2002년 국제협력법은 중점협력국을 25국에 서 18 개로 축소

- ODA 규모의 확대

- 2003년 벨기에 정부부처 개편안인 Copernic Plan에 의해 종전의 국제협력부 (DGIC)가 외무부 내로 편입, 개발협력사무 국 (DGDC)으로 확대변경

-DGIC:Directorate General for International Cooperation

-DGDC:Directorate General for Development Cooperation - 2003년부터 개발협력 장관 임명

\section{ODA 규모, 주요 수원국 및} 지원현황

\section{ODA규모}

(단위: USD million , \%)

\begin{tabular}{c|c|c}
\hline 연 도 & 지원규모(GNI 대비) & 양자원조비율 \\
\hline 2003 & $1,850(0.60 \%)$ & - \\
\hline 2004 & $1,460(0.41 \%)$ & - \\
\hline 2005 & $1,963(0.53 \%)$ & $67 \%$ \\
\hline 2006 & $1,978(0.50 \%)$ & $69 \%$ \\
\hline
\end{tabular}

\section{2. 상위 10 대 수원국}

\begin{tabular}{c|c|c}
\hline 순위 & 국가 & 금액 (USD million) \\
\hline \hline 1 & 콩고민주공화국 & 192 \\
\hline 2 & 나이제리아 & 170 \\
\hline 3 & 이라크 & 124 \\
\hline 4 & 카메룬 & 42 \\
\hline 5 & 르완다 & 32 \\
\hline 6 & 부룬디 & 28 \\
\hline 7 & 남아공 & 21 \\
\hline 8 & 세네갈 & 20 \\
\hline 9 & 에쿠아도르 & 20 \\
\hline 10 & 베트남 & 19 \\
\hline
\end{tabular}

\section{3. 수원국}

- 협력국가 : 총 18 개국

- 알제리, 베냉, 볼리비아, 부룬디, 콩고민주공 화국, 에쿠아도르, 말리, 모로코, 모잠비크, 니제르, 팔레스타인, 페루, 르완다, 세네갈, 남아프리카, 탄자니아, 우간다, 베트남 $※ 18$ 개 국가 중 10 개국은 최빈개도국(LDCs)

- 취약국가에의 지원: 분쟁예방과 사회통합 차원 
에서 취약국가에 대한 지원을 우선시함

- 지난 5년간 중앙아프리카 국가들에 대한 지 원은 약 $60 \%$ 를 차지

\section{III. 원조기관 및 운영체계}

\section{DGDC : Directorate General For} Development Cooperation

\section{BTC (Belgian Technical Cooperation)}

- $\mathrm{DGDC}$ 에서 위임받은 벨기에 양자 개발원조 실행 기관(1998년 설립)

- 30 개국에 200 개 이상 프로그램 수행

- 총 420 명 직원 중 160 명이 브뤼셀, 260 명은 24 개의 해외사무소 근무

- 프로젝트 발굴, 실행 및 평가 단계에 있어 $\mathrm{DGDC}$ 와 $\mathrm{BTC}$ 의 권한 범위에 혼선 발생

- $\mathrm{DGDC}$ 는 양자간 원조 정책 수립: 협력프로그 램 준비 및 조정, 예산 및 통계 담당

- $\mathrm{DGDC}$ 는 외무부에 속하며, 6 개 부처 중 하나

- DGDC는 5 개의 directorates와 4 개의 support service 부서로 구성

- 직접 양자지원은 $\mathrm{DGDC}$ 가 집행, 간접 양자지 원은 NGOs, 대학 등 여타기관들이 시행

- $\mathrm{DGDC}$ 는 $\mathrm{ODA}$ 의 $60 \%$ 집행, 재무부는 $\mathrm{ODA}$ 의 $10 \%$ 집행

\section{IV. 원조의 언타이드 현황}

- 벨기에는 언타이드와 관련 재경부와 갈등을 겪고 있으며 단계적으로 언타이드를 실시

- 비용 효과성 제고가 언타이드 확대의 주요 논리

- 2003년 벨기에의 최빈국에 대한 원조중 $99.1 \%$ 가 언타이드

- DGDC는 Belgian Technical Cooperation (BTC)에 원조프로그램 실행 위임

\section{$\mathrm{V}$. 중점지원 분야}

\section{2006년 DGDC예산 배분}

\begin{tabular}{c|c}
\hline \multicolumn{2}{c|}{2006 DGDC예산 } \\
\hline 정부 개발협력 & $25 \%$ \\
\hline NGOs & $22 \%$ \\
\hline 다자개발 협력 파트너 & $40 \%$ \\
\hline $\begin{array}{c}\text { Belgian Survival Fund } \\
\text { 및 인도지원프로젝트 }\end{array}$ & $13 \%$ \\
\hline
\end{tabular}

\section{1. 중점지원 분야 5 가지}

- 기초보건, 교육훈련, 농업과 식량안전, 기초인 프라, 분쟁예방과 사회통합

- Cross-cutting Issue : 성 평등, 환경, 사회경 제분야 


\section{2. 분야별 지원현황}

\section{(2005년 양자간 ODA기준)}

- 부채탕감에 대한 지원 비율이 높음

- 사회 인프라 중 교육 및 굿거버넌스에 대한 지 원 비율이 가장 높음

- 기초교육 및 기초보건에 대한 비율은 저조

\section{VI. 사업 형태}

- 기술협력, 설비투자, 현금성 지원, 기타(식량 지원, 인도적지원, 부채탕감)

- 기술협력은 교환프로젝트(전문가 파견, 봉사 단 파견, 연수과정)와 지식 공유 프로젝트(연 구 지원, 개도국 내 연수과정 설립 운영, 세 미나 워크숍 개최 등)가 있음

- 설비투자는 물자지원, 인프라 건축으로 나뉨

- 현금성 지원은 예산지원, NGO지원, Microfinance, 기타 식량지원, 인도적지원, 부채
탕감, 인식 확산 캠페인이 있음

• 벨기에는 현재 7 개 파트너 국가의 보건과 교육분야에 현금성 지원을 하고 있음

\section{ODA 홍보전략}

- Eurobarometer에 따르면, 개도국에의 원조 가 중요하다고 생각하는 국민의 비율은 1998 년 55\%, 2002년에 71\%, 2004년에 86\%로 증 가했으나 아직 유럽의 평균인 $91 \%(2004)$ 에는 못 미치는 실정임

- 개발원조에 관한 여론지지를 높이기 위해 관 련 예산을 2000년도에 $13.3 \mathrm{EUR}$ million에 서 2003년 18.1 million EUR 로 증대

- BTC는 개발원조에 대한 홍보에 있어서 중요 한 파트너인데, Annoncer la couleur/Kleur bekennen 프로그램을 시행

- 이는 학교 학생들과 선생님들에게 개발에 관 한 교육자료를 제공하는 프로그램임 
첨부 1 : 벨기에 외무부 조직도

\section{Organization chart}

The EPS Foreign Affairs, Foreign Trade and Development Cooperation

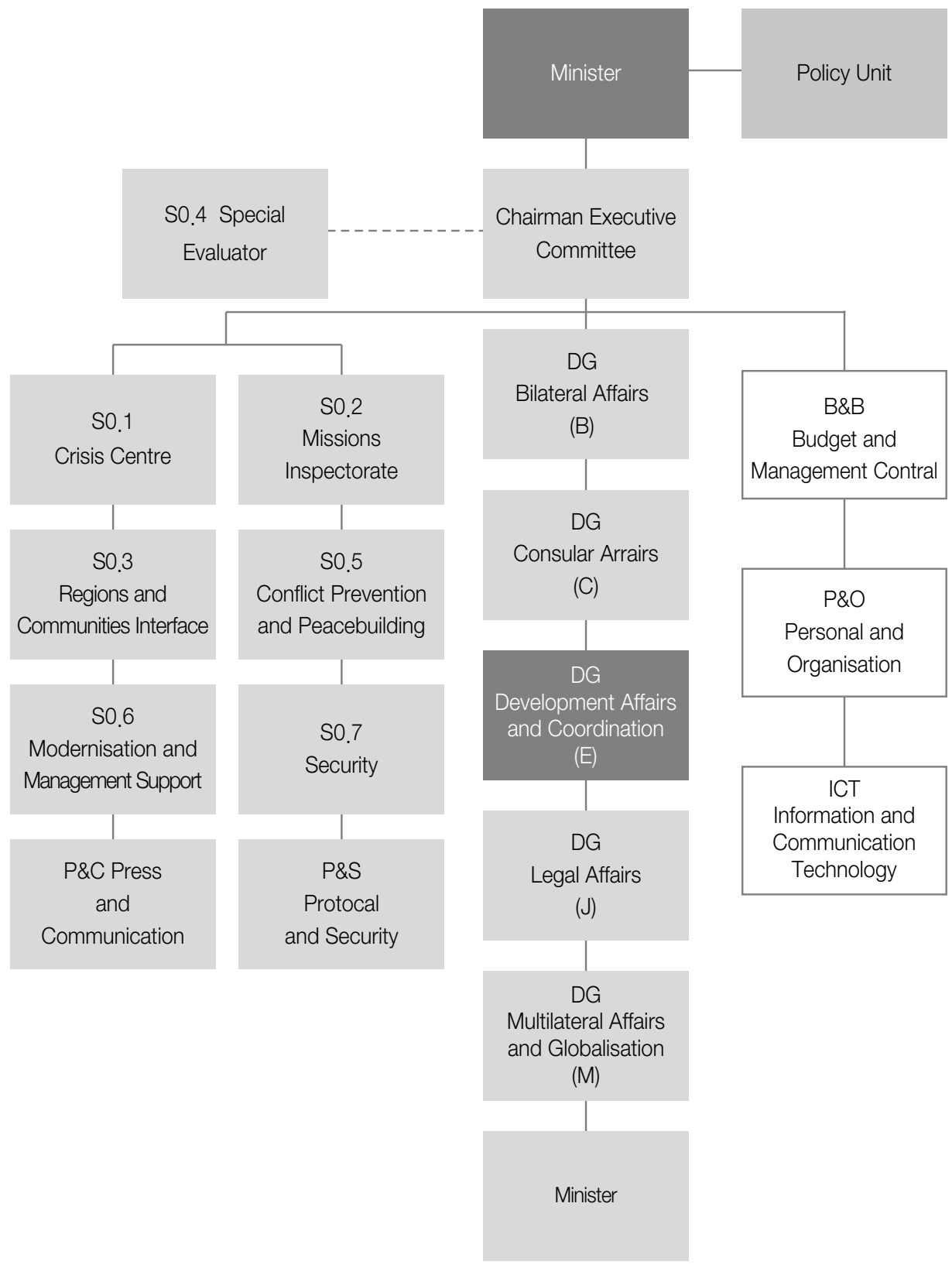


첨부 2 : $\mathrm{DGDC}$ 조직도

The Directorate-General for Development Cooperation (DGDC)

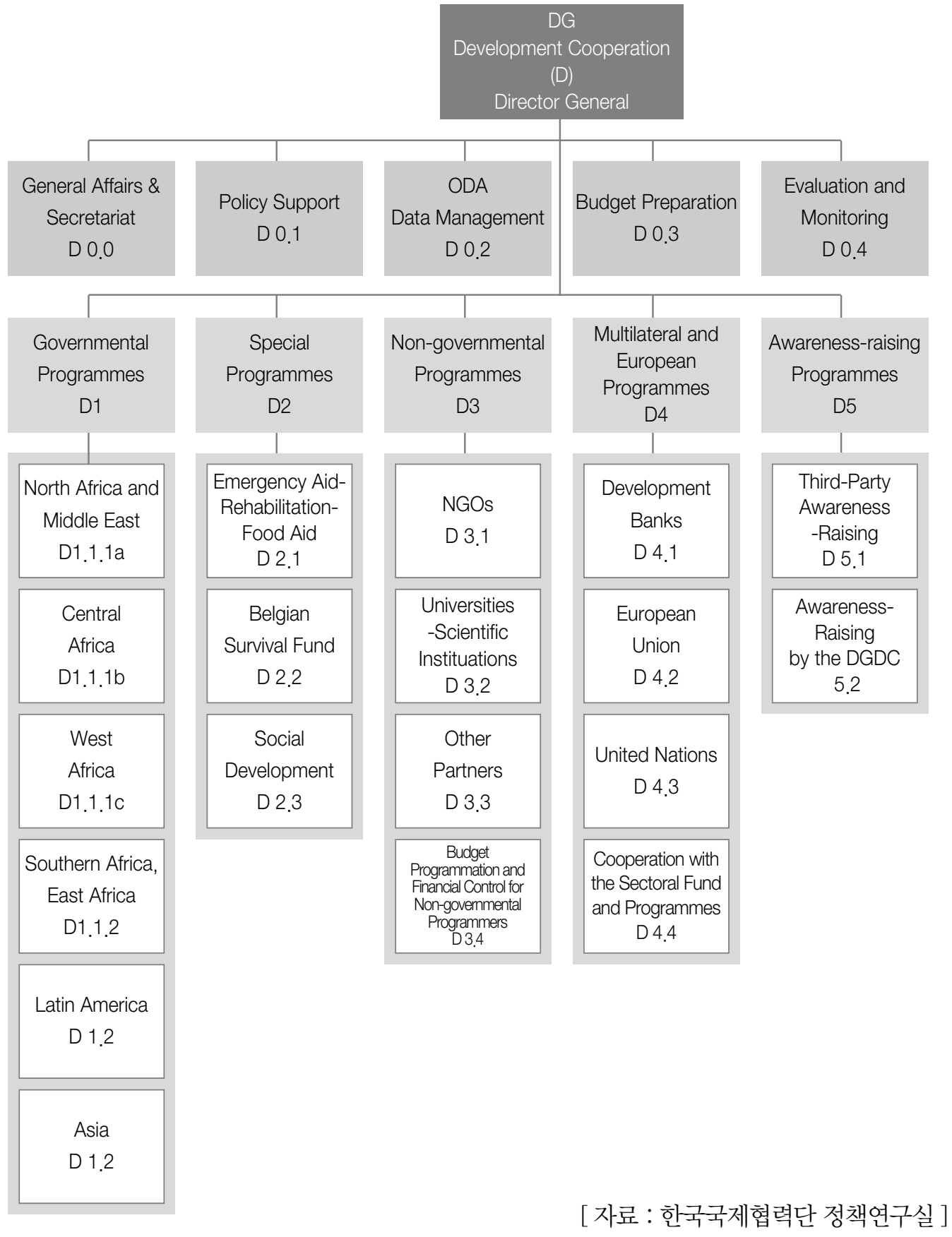

